\title{
Design of Poultry Business Development Model Towards Formal Financing Facilities
}

\author{
Mursalim Nohong ${ }^{1}$ \\ Amiruddin Amrullah ${ }^{2}$ \\ Palmarudi ${ }^{3}$ \\ 1,2 Faculty of Economics and Business, Hasanuddin University Indonesia \\ ${ }^{3}$ Faculty of Animal Husbandry, Hasanuddin University Indonesia
}

\begin{abstract}
This research aims to; 1). Identify and map the amount of additional funding for working capital and investment required by laying chicken breeders as well as the sources of funding used so far, 2). Identify and map the driving forces and barriers of laying chicken business by the business scale in utilizing funding from formal financial institutions, 3). Assess the feasibility of laying chicken business by the business scale in utilizing funding from the formal financial institution, and 4). Design a financing scheme from a formal financial institution that is suitable for the laying chicken farming business. This research begins by identifying additional funding for working capital and investment purposes. The second stage identifies the driving forces and constraints of the business. The third stage is a business feasibility study and the design of funding schemes from formal financial institutions.

The data were collected in Sidenreng Rappang and Pinrang districts on 60 sample farmers which were then proportionally allocated ie 30 samples for each district. The results showed that the age of respondent farmers in the study area is in the range 25 - 55 years and over. Most of the breeders are still at a productive age (25 - 55 years old), which is 55 farmers $(91.66 \%)$ while the remaining $5(8.33 \%)$ are over 55 years old. The age composition of respondent farmers, most of the productive age is a positive opportunity because productive age farmers have stronger and more open physical capabilities in accepting new innovations related to the livestock business development practices they manage. Similarly, in managing funds obtained from bank financial institutions.

Some of the driving factors for livestock business development are land availability, production capability, government support, market growth, experience, and economic motivation. The inhibiting factors include price fluctuations, death risk, capital, farmer behavior and non-financial finance support. Based on the analysis results found that laying chicken business has prospects financed and developed.
\end{abstract}

Keyword: Design model, funding, formal financing 


\section{A. Background}

Laying chicken farming business has an important role in the economy of South Sulawesi. This is because these efforts are not only able to improve the quality of human resources through the provision of animal protein but also to be a source of income and provide employment is not only limited in rural but also in urban areas. According to the Head of Animal Husbandry Office of Sidrap Regency (www.fajar.co.id, 20 November 2012), the income of farmers obtained from laying chickens in Sidrap Regency reaches Rp79 billion every day, and the number of household farmers in this area reaches 1,336 households, with direct labor absorption of 1,740 people and indirect labor of about 348 people.

The potential population of laying chicken in South Sulawesi is the largest in Eastern Indonesia (KTI). According to data from the Directorate General of Animal Husbandry and Animal Health, the population of laying chicken in South Sulawesi in 2014 is 78.03 percent of the total population of laying chicken in KTI (12.464.052 head). The population of laying chickens in South Sulawesi during the last five years showed a rapid growth, in 2009 the population of laying chickens as much as $6,458,425$ heads and increased to 9,438,956 tails or grew by 13.68 percent higher than the average growth in national $(5.48 \%)$. In the same year period, the production of chicken eggs in 2010 was 45,903 and increased to 72,774 in 2014 with a growth of 13.68 above the national average of 6.11 percent ((Directorate General of Animal Husbandry and Health, 2015) a large population, the business of laying chicken in South Sulawesi from the business aspect is also very profitable to be developed.Because of the supply side, the production capacity of eggs in South Sulawesi is still not reached the actual production capacity.It is seen from the production of chicken eggs only reached $43.92 \%$ of the total production of poultry eggs (BPS Sulawesi Selatan, 2013) In terms of demand, egg demand will always increase chicken eggs because eggs are elastic to changes in income According to Rombe and Pantjawidjaya (2012) egg consumption of South Sulawesi population only reached $2.3 \mathrm{~kg} /$ capita/day under the standard of cons national use of 7.86 grams/capita/hair, If the egg consumption is compared, then there will be market opportunities for the development of chicken farming business laying chicken. In addition, the chicken egg eggs market opportunities. of South, Sulawesi is still wide open in the KTI region and export markets, both in the form of fresh eggs and processed eggs.

various financing/credit schemes provided by formal financial institutions cannot be optimally utilized by laying chicken breeders due to various obstacles inherent in the business of laying chicken farming. Meanwhile, all the financing schemes provided by formal financial institutions are in the form of general financing schemes for all business sectors and business scale. So there is no credit scheme specific to laying chicken business and business scale. Studies have shown that laying chicken farmers who face obstacles in exploiting the credentials of formal financial institutions have low production and income (Afolabi et al., 2014). On the basis of the argument, the study of increasing the laying of chicken farms towards formal financing is very urgent to do. 


\section{B. LITERATURE REVIEW}

\section{General Overview Laying Chicken Farm}

According to the Decree of the President of the Republic of Indonesia No. 22 of 1990, Articles 1 and 3 that the meaning of chicken breeding business is laying layer chicken laying breeding race excluding nurseries, which operate for people's livestock, individuals, groups, and cooperatives. In addition, laying chicken can also be done by National Private and Domestic Investment Company (PMDN) by observing that the cultivation of chicken can be done by Foreign Investment Company (PMA) with the obligation to export at least $65 \%$ (sixty-five percent) of its Production. Furthermore, according to Decree of Minister of Substitution of Presidential Decree 22/1990, Livestock Ranch is defined as a livestock business which is carried out as a side business with the maximum amount of business per species of livestock in accordance with the list of attachments. Meanwhile, livestock companies that already have a business license can expand their business after obtaining a business license. Approval is not required if the addition of livestock population does not comprise $30 \%$ of the number of livestock permitted. The issued business license may be revoked if the company does not engage in any real activity for 3 months after the issuance of the license. Or stop his business activities for one year in a row. (Trubus, 2002).

Laying chicken farming business has grown very rapidly, this is due to various factors, among others, improve the efficiency of chicken farming because of increasing the skills of farmers in applying advanced technology, and the encouragement and guidance of the government. Increasing demand for egg commodities, as well as the rapid development of chicken breeding companies, cattle fodder factories and medicines in the country (Yassin and indarsih1988). Laying chicken farming is a biological industry activity, where success is determined by the procurement of production facilities, seeds, fodder and the accuracy of management and production of marketing products. However, animal feed components play an important role in ensuring the viability of a business (Rsyaf, 1996). Resumed by rasyaf (1996) which states that laying chicken is known two kinds, laying the skin of brown and white skin. Both are actually the same and the nutritional content of the same relative, which is different from the point of view of the buyer who considers the eggs more attractive brown, bigger, and more delicious even this is not proven. The problem of tasty or uncomfortable must be through a taste test that is relative. But the result of the buyer's view that causes brown chicken eggs more demand. 


\section{Financial Institutions}

Financial Institutions are defined as any company engaged in finance, raising funds, channeling funds, or both. Activities undertaken by these financial institutions are always related to the financial field. Financial institutions are classified into two major categories in practice, namely: financial institutions of banks and other financial institutions (finance institutions). Banks are a very important financial institution in the economy, especially in the monetary system. In general, banks are defined as financial institutions whose main business is to raise funds and distribute them to the public in the form of credit and provide services in the traffic payments and circulation of money. According to Act No. 10 of 1998 on Banking, banks are defined as business entities that collect funds from communities in the form of savings and redistribute them in the form of loans (credit) and/or other forms in order to improve people's lives.

\section{RESEARCH METHODS}

\section{Research Sites and Analysis Units}

The unit of analysis of this study is laying chicken breeders who have never obtained capital/credit from formal financial institutions. The number of analytical units used as the sample of respondents is as much as 60 breeders with the consideration that the number has exceeded the minimum sample size in the study as Likert said that the samples were taken at least $30,50,75,100$ or multiples (Riduwan, 2008).

Of the 60 sample farmers, it is then allocated proportionally based on the sample regency, i.e. 30 farmers in Sidenreng Rappang District, especially in Kecamatan Maritengngae and Kecamatan Baranti and 30 farmers in Pinrang District in Mattiro Bulu and Suppa Subdistricts. Considering that there is no sampling frame available, the technique of determining sample of respondent farmer will use Snowball sampling technique to find some farmers of respondents in two sub-district locations that have never obtained capital / credit from formal financial institution and based on recommendation or information from the initial breeder's respondents traced by other breeders so the number of breeders of respondents reached 60 breeders.

\section{Analysis Method}

Data analysis in this study will be conducted with three analytical methods, namely:

\section{1) Cluster Analysis}

The cluster analysis in this study will be used to map the extent of additional funding for working capital and investment required by farmers and the sources of funding used so far, and to map the potential and business constraints of laying chicken based on a business scale in utilizing credit from formal financial institutions. The cluster analysis in this study uses business scale determination formula based on the number of livestock ownership cultivated. Determination of frequency 
distribution limits with a class length according to Sudjana (1992) is to determine the range of the largest ownership minus the smallest ownership, then divided by the length of the class. The division of business scale is based on the formula:

$$
\text { Interval }=\frac{\text { Range }}{\text { Distant Class }}
$$

\section{Comparative Analysis}

The comparative analysis of inhibiting and promoting factors in this assessment will be used to assess livestock enterprises according to the scale of business feasible to obtain financing from formal financial institutions. Assessment criteria, chicken breeding business is considered feasible to get financing from formal financial institutions if the number of factors pushing more than the obstacles factor.

\section{RESULTS AND OUTCOME}

\section{Research result Cluster analysis}

The cluster analysis in this study focuses on the ownership of laying chicken as shown in Table 1.

Table 1. Cluster breeders based on the ownership of laying chicken

\begin{tabular}{lll}
\hline No & Cluster & Interval \\
\hline $\mathbf{1}$ & Cluster I & $450-9.960$ \\
$\mathbf{2}$ & Cluster II & $>9.960-19.470$ \\
$\mathbf{3}$ & Cluster III & $>19.470-28.980$ \\
$\mathbf{4}$ & Cluster IV & $>28.980-38.490$ \\
$\mathbf{5}$ & Cluster V & $>38.490-48.000$ \\
\hline
\end{tabular}

Source: Data processed, 2017

\section{Average of sales turnover by Cluster}

Laying chicken farming in Sidrap and Pinrang regencies has become a source of income for the community and government. Its existence is not only felt by the community individually, especially farmers. This effort also has a positive impact on the income of other communities and the government. One of the developments achieved can be seen from the sales turnover of each breeder.

Based on the data as shown in Figure 1 shows that the average sales turnover of laying hens for cluster I am Rp.35.266.667. For cluster II, the average 
sales turnover is Rp.118.200.000, -, cluster III of Rp. 241.000 .000 , while cluster V is equal to 300.000 .000 .

\section{Figure 1 Average of sales turnover by Cluster}

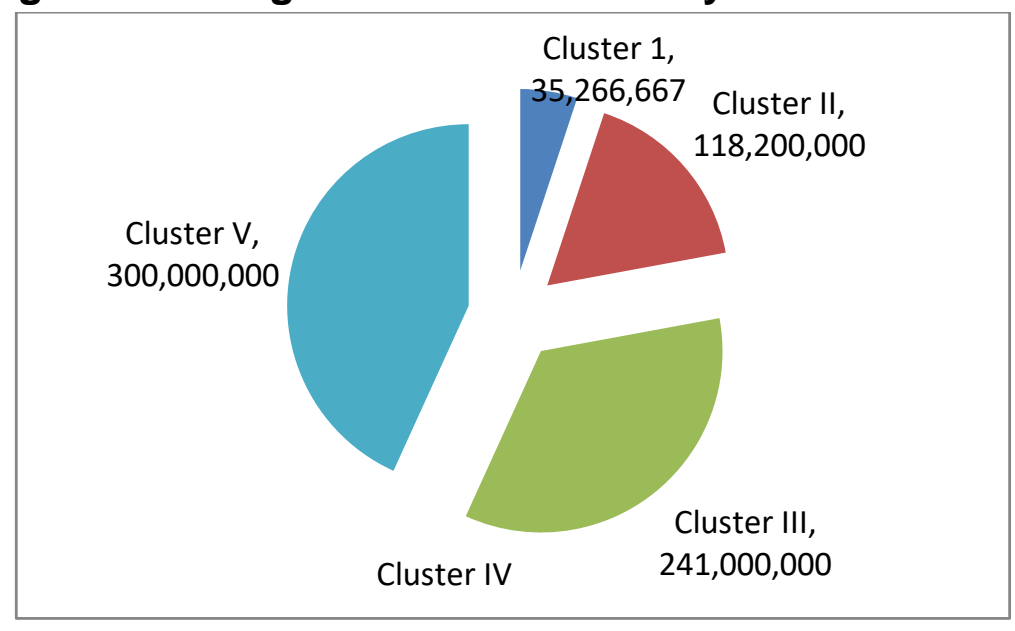

Source: Primary Data, 2017

If the comparison between the average sales turnover with the average number of laying chickens managed, it can be explained the productivity of each cluster. In detail, the average productivity of cluster I obtained the value of Rp.6.776 per head, cluster II with the average of 14,715 heads obtained productivity value of Rp.8.033 per head per month. In the meantime, for cluster III obtained productivity value of Rp.9.948 per head per month while for cluster $\mathrm{V}$ obtained productivity value of Rp. 6,937 per head per month.

Based on these production values, it appears that cluster III is the most productive cluster. This cluster in business management or cultivation has 450 9,960 chickens able to generate income or turnover of Rp.9.948 per head per month. When compared with other clusters, then cluster 1 is a cluster with the lowest productivity that is only Rp.6.776 per head per month.

\section{Financing sources by Cluster}

In running the laying chicken business, farmers in Sidrap and Pinrang districts use financing sources in the form of family loans, savings, friend loans, and bank loans as shown in Table 2. 
Table 2 Financing Source by Cluster

\begin{tabular}{|c|c|c|c|c|c|c|c|c|}
\hline \multirow{2}{*}{$\begin{array}{l}\text { Financing Source } \\
\text { Family Loan }\end{array}$} & \multicolumn{2}{|c|}{ Cluster I } & Cluster II & \multicolumn{2}{|c|}{ Cluster III } & Cluster IV & \multicolumn{2}{|c|}{ Cluster V } \\
\hline & 14 & 48.181 .818 & 20.000 .000 & 1 & 20.000 .000 & - & & - \\
\hline Saving & 14 & 158.400 .000 & 130.000 .000 & 1 & - & - & 2 & 100.000 .000 \\
\hline Friends' Loan & 7 & 82.857 .143 & 130.000 .000 & 1 & - & - & & - \\
\hline Bank & 24 & 313.620 .690 & 266.000 .000 & - & 99.000 .000 & - & 3 & 25.000 .000 \\
\hline Investor & & - & - & & - & - & & - \\
\hline Stockholder & & - & - & & - & - & & - \\
\hline Main Company & & - & - & & - & - & & - \\
\hline
\end{tabular}

Source: Primary Data, 2017

Based on Table 2 it appears that as many as 24 farmers who use bank loans as a source of financing with the average value of bank loans amounted to Rp.313.620.690. A total of 14 farmers who each use a family loan and savings with an average value of Rp. 48,181,818 and Rp.158,400,000. In addition, there are 7 farmers who manage their business using funds sourced from friends with an average value of $\mathrm{Rp}$. 82.857.143.

In Cluster II, farmers use bank loans and family loans as a source of financing for laying chicken business with a loan value of Rp.266,000,000 and Rp.20,000,000. In addition to sourced from banks in the form of bank loans and family loans, the farmers also rely heavily on personal savings and loans to develop their business friend.

Table 2 also provides information related to sources of financing made by the farmers grouped in cluster V. In the table, it appears that from 75 farmers who responded in this study, there are 3 farmers who use the source of financing in the form of bank debt with the value average loan of $\mathrm{Rp} 25,000,000$. In the meantime, as much as 2 farmers who use a friend loan with an average loan value of Rp. 100.000 .000 , as a source of financing.

5.2.8 Use of funds by Cluster

In general, in a business or investment, the existence of funds is for working capital and investment or business development. Information on the use of funds by laying chicken breeders as shown in Table 3. 
Table 3 Use of laying chicken breeders

\begin{tabular}{|c|c|c|c|c|c|c|c|c|c|}
\hline \multirow{2}{*}{$\begin{array}{l}\text { Use of Funds } \\
\text { Working capital }\end{array}$} & \multicolumn{2}{|c|}{ Cluster I } & \multicolumn{2}{|c|}{ Cluster II } & \multicolumn{2}{|c|}{ Cluster III } & \multicolumn{2}{|c|}{ Cluster IV } & Cluster V \\
\hline & 36 & 250.817 .143 & 3 & 63.000 .000 & 1 & 19.000 .000 & - & - & 25.000 .000 \\
\hline Building land/ & 29 & 143.103 .448 & 2 & 315.000 .000 & 2 & 140.000 .000 & - & - & 100.000 .000 \\
\hline \multicolumn{10}{|l|}{ Equipment } \\
\hline \multicolumn{10}{|l|}{$\begin{array}{l}\text { Research and } \\
\text { development }\end{array}$} \\
\hline Promotion & & & & & & & & & \\
\hline
\end{tabular}

Source: Primary Data, 2017

Based on the data in the table, it appears that for cluster I, funds obtained from several sources are used for working capital with a value of Rp. 250.817.143 while the rest for the purposes of Land / Building / Equipment with an average value of Rp. 143.103.448.

For cluster II as many as 3 farmers who use the funds for working capital with a value of Rp.63.000.000 while 2 farmers use funds of Rp. 315 million for Land / Building / Equipment purposes. For cluster III there is 1 farmer using the fund for working capital need with a value equal to Rp.19.000.000, - and as much as 2 farmers who use funds obtained for the purpose of Land / Building / Equipment with an average value of Rp.140 million.

Cluster $V$ as shown in Table 3 shows that there is 1 farmer who uses his fund for working capital with an average value of Rp.25 million while the other uses Rp. 100 million for Land / Building / Equipment purposes

\section{Comparative analysis as the basis for the feasibility assessment}

Based on the analysis obtained some supporting and inhibiting factors for laying chicken farming in Sidrap and Pinrang regencies in accessing financing institutions as in Table 4:

Table 4 Table of supporting and Obstacles factors

\begin{tabular}{l|ll|l}
\hline Supporting Factors & \multicolumn{3}{l}{ Obstacles Factors } \\
\hline Land availability & 2 & Price fluctuations & 2 \\
\hline Production capability & 3 & The risk of death & 1 \\
\hline Government support & 1 & Capital & 2 \\
\hline Market growth & 3 & Behavior breeders & 2 \\
\hline Experience & 2 & Capital & 2 \\
\hline Economic motivation & 2 & Non-financial support & 1 \\
\hline amount & 13 & amount & 10 \\
\hline
\end{tabular}

Source: Primary Data, 2017 
Based on comparative analysis between the supporting and inhibiting factors where the number of perceptual values for the driving factors is greater than the inhibiting factors. Based on the results of the analysis, it can be concluded that the business of laying hens in Sidrap and Pinrang regencies is eligible to obtain financing from financial institutions.

\section{E. CONCLUSION}

The results showed that the age of respondent farmers in the study area is in the range 25 - 55 years and over. Most of the breeders are still at a productive age (25 - 55 years old), which is 55 farmers (91.66\%) while the remaining $5(8.33 \%)$ are over 55 years old. The age composition of respondent farmers, most of the productive age is a positive opportunity because productive age farmers have stronger and more open physical capabilities in accepting new innovations related to the livestock business development practices they manage. Similarly, in managing funds obtained from bank financial institutions.

Some of the driving factors for livestock business development are land availability, production capability, government support, market growth, experience, and economic motivation. The inhibiting factors include price fluctuations, death risk, capital, farmer behavior and nonfinancial finance support. Based on the analysis results found that laying chicken business has prospects financed and developed. 


\section{REFERENCE}

Anonim. 2006. Pemetaan Komoditas Pertanian Unggulan Jawa Barat serta Potensi Pem-biayaan Perbankan Syariah untuk Pengem-bangannya. Kerjasama Kantor Bank Indo-nesia Bandung dengan Pusat Analisis Sosial Ekonomi dan Kebijakan Pertanian.

Anonim. 2008. Karakteristik Perbankan (Pengertian, Fungsi, dan Ruang Lingkup Usaha Bank) URL:.http://blognyamyun.blogspot.com/2008/08/karakteristik-perbankanpengertian.html

Anonim. 2009. Pengertian dan Fungsi Bank. URL: http://www.edukasi.net/mol/mofull.php?moid=7\&fname=eko203_18.htm $[7 / 1 / 09]$

Arifin, B. 2007. Mengatasi Kesulitan Pembiayaan Sektor Pertanian. URL: http://barifin.-multiply.com/j ournal/item/17 [23/10/2007]

Ashari dan S. Friyatno. 2006. Perspektif Pendirian Bank Pertanian di Indonesia. Forum Agro Ekonomi, 24 (2): 107-155. Pusat Analisis Sosial Ekonomi dan Kebijakan Pertanian. Badan Penelitian dan Pengembangan Pertanian.

Aviliani. 2009. Kebijakan Perbankan dalam Sektor Agribisnis. Makalah disampaikan pada Round Table Discussion: Mencari Alternatif Pembiayaan Pertanian. Kerjasama Kemen-terian Koordinator Bidang Perekonomian dan Departemen Agribisnis, FEM-IPB. Jakarta, 16 April 2009.

Bank Indonesia. 2006. Laporan Perekonomian Indonesia 2006. Bank Indonesia, Jakarta.

Departemen Pertanian. 2007. Revitalisasi Pertanian (Agriculture Revitalization). Departemen Pertanian. Jakarta.

Dinas Peternakan Kabupaten Sidenreng Rappang. 2011. Pemda Kabupaten Sidenreng Rappang. http://www.sidenrengrappangkab.go.id/peter

Direktorat Jenderal Peternakan Dan Kesehatan Hewan. 2013. Statistik Peternakan Dan Kesehatan Hewan 2013. Direktorat Jenderal Peternakan Dan Kesehatan Hewan.. 
Halim H., Salam, T, dan Muis, M., 2007. Tatalaksana Pemeliharaan dan Analisis Usaha Peternakan Rakyat Ayam Ras Petelur Fase Layer, Jurnal Agrisistem, Juni 2007, Vol 3 No. 1, hal. 44-53

Kusnadi, U., 2014. Level of Income and Ability of Self-Help Broiler Chicken Farmer in Returning Capital Loan and Investment in Pandeglang District, paper, Seminar Nasional Teknologi Peternakan dan Veteriner 2004

Kuncoro, M., 2004, Otonomi \& Pembangunan Daerah: Reformasi, Perencanaan, Strategi dan Peluang, Erlangga, Jakarta

Mumammah, E.N., 2008. Aalisis Faktor-Ofaktor Yang Mempengaruhi Tingkast Pengembalian Kredit Oleh UMKM,Tesis, Program Studi Manajemen Agribisnis, Fakultas Pertanian Institut PertanianBogor

Nurmanaf, R., 2003. Tingkat Konsumsi Telur dan Variasi Keseimbangan ProduksiKonsumsi Antar Provinsi di Indonesia, WARTAZOA Vol. 13 No. 4 Th. 2003, hal. 152-158

Nuryati, Y. dan Nur, Y.H., 2012. The Variability of Price of Ras Chicken Eggs In Indonesia Buletin IImiah Litbang Perdagangan, VOL.6 NO.2, DESEMBER 2012, hal. 235-352

Parasdya, W., Mastuti, S dan Djatmiko, O.E., 2013. Analisis Finansial Usaha Peternakan Aayam Ras Petelur Di Kecamatan Kademangan Kabupaten Blitar, Jurnal IImiah Peternakan 1(1):88-98, April 2013

Ramdhansyah dan Silalahi, S.A., 2013. Pengembangan Model Pendanaan bagi UMKM Berdesarkan Persepsi UMKM, Jurnal Keungan dan Bisnis, Vol. 5 No.1Maret 2013, hal. 31-39

Rangkuti, F., 2000 Analisis SWOT Tehnik Membedah Kasus Bisnis.

Rombe, M.B dan Pantjawidjaya, S. 2012. Peternak Ayam Petelur Serta Konsumen Paham Terhadap Nilai Gizi Telur Merupakan Suatu Kunci Pangsa Pasar Dalam Agribisnis, URL : download.portalgaruda.org/article.php?article

Syukur, M., E.L. Hastuti, Soentoro, A. Supriatna, Supadi, Sumedi, dan B.W.D. Wicaksono. 2002. Kajian Pembiayaan Pertanian Men-dukung Pengembangan Agribisnis dan Agroindustri di Perdesaan. Pusat Penelitian dan Pengembangan Sosial Ekonomi Per-tanian. Badan Penelitian dan Pengemba-ngan Pertanian.

Zainal dan Chris. 1991. Pembangunan masyarakat Desa. Bina Cipta. Bandung. 
Veithzal Rivai dan A. P. Veithzal. 2006. Credit Manajement Handbook :. Teori, Konsep, dan Aplikasi Panduan Praktiks Mahasiswa, Bankir, dan Nasabah. Penerbit Raja Grafindo Persada. Jakarta. 